\title{
Bioremediation Potentials and Emulsification Activity of Indigenous Bacteria Isolated from Crude Oil Polluted Soil in Ohaji-Egbema, Nigeria
}

\author{
Okonkwo N. N., Chukwura E. I., Mbachu A. E.* \\ Department of Applied Microbiology \& Brewing, Faculty of Biosciences, Nnamdi Azikiwe University, Nigeria
}

Received January 10, 2020; Revised March 4, 2020; Accepted March 19, 2020

Copyright $\odot 2020$ by authors, all rights reserved. Authors agree that this article remains permanently open access under the terms of the Creative Commons Attribution License 4.0 International License

\begin{abstract}
Crude oil pollution is a global problem because of its hazardous effect to aquatic and terrestrial life, as well as having adverse effect on soil productivity. Bioremediation technology has been established as a successful alternative to physicochemical technique in cleaning up of contaminated site. This study was aimed at determining the bioremediation potentials and emulsification activity of indigenous bacteria isolated from crude oil polluted soil. Soil samples were randomly collected from Water-Smith and Base-Camp refineries in Ohaji-Egbema Local Government Area of Imo State, Nigeria. Bacteria isolation and identification were done using standard methods. The isolates were screened for crude oil biodegradation potential, and the extent of crude oil removal was determined using gravimetric method. Emulsification activity of the isolates was also determined using emulsification index (E24). Data were analyzed using analysis of variance (ANOVA) at $\mathrm{P}<0.05$. Bacteria isolates such as Arthrobacter sp., Enterobacter sp., Bacillus sp. and Pseudomonas sp. were identified in this study. Pseudomonas sp. achieved the highest extent of crude oil removal within the experimental period. Moreover, highest $\mathrm{E}_{24}$ of $81.80 \pm 2.8$ and $84.00 \pm 4.0$ was recorded in the media containing Bacillus sp. and Pseudomonas sp., respectively at $0.75 \mathrm{mg} / 1$ crude oil concentration. Among the isolates, Pseudomonas sp. has greater potential for effective bioremediation of crude oil polluted soil as well as biosurfactant production due to its higher biodegradation efficiency and emulsification activity.
\end{abstract}

Keywords Biodegradation Potential, Ohaji-Egbema, Bioremediation, Emulsification Activity, Crude Oil

\section{Introduction}

Crude oil, commonly referred to as petroleum, is a liquid found within the earth comprised of hydrocarbons, organic compounds and small amount of metals [1]. Crude oil which is abundantly located in the Niger Delta region of Nigeria is spilled on the environment due to pipeline rupture, oil well blowout, oil tanker wreckages, oil bunkering to mention but a few. Crude oil spill can also occur at different stages of production and transportation either for export or refining processes.

The petroleum hydrocarbons are hazardous to various forms of terrestrial and aquatic life and are also carcinogenic, mutagenic and potentially immunotoxigenic $[2,3]$. The economic life of the people in the affected area is disrupted. Farmlands, navigational activities, availability of potable water and fishing activities are jeopardized. Previous studies on crude oil pollution in soil had revealed its adverse effects on soil productivity $[4,5]$.

The traditional physical and chemical treatments to clean up the petroleum hydrocarbons are expensive and appear ineffective. This is because they do not lead to complete mineralization, and awfully can produce toxic byproducts or residues [2,3]. In contrast, bioremediation involving microbial agents, such as protozoa, bacteria, fungi, plants; offers successful alternatives to clean up the petroleum pollution [2]. Bioremediation technology is safe, economical, more efficient and reliable method that is harmless and eco-friendly $[6,7]$.

The effect of exogenously added microbial biosurfactants in enhancing the bioremediation of crude oil-polluted soils by indigenous microbes have been reported [8,9]. Biosurfactant producing microorganisms are commonly found in different environments, such as soil or water samples that are contaminated with hydrophobic organic compounds (i.e., oil contaminated soils) like refinery wastes $[8,10]$. Moreover, biosurfactants 
have a wide array of applications such as; emulsifiers, de-emulsifiers, wetting agents, spreading agents, foaming agents, functional food ingredients, as well as detergents [11]. Due to their unique properties and vast array of applications, sourcing of new biosurfactant producing microbes is currently in great demand [9]. Biosurfactants emulsify oil thereby enhancing its removal from the environment.

This study was therefore undertaking with a view to determine the bioremediation potentials and emulsification activity of indigenous bacteria isolated from crude oil polluted soil.

\section{Materials and Methods}

\subsection{Collection of Samples}

Crude oil polluted soil samples were randomly collected using hand auger at a depth of $3-5 \mathrm{~cm}$, from four different locations at the Water-Smith and Base-Camp refineries in Umu-Akpu, Ohaji and Awaraka Communities, both in OhajiEgbema Local Government Area of Imo State. Crude oil used in this study was also collected from the refineries. Samples were placed in sterile bottles and transported immediately in cold storage container to the laboratory.

\subsubsection{Sample Site Description}

OhajiEgbeme is an oil-rich Local Government Area of Imo State, Nigeria. It is located in the South-western part of Imo State, shares common boundaries with Owerri in the East, Oguta LGA in the North and Ogba/Egbema/Ndoni in Rivers State in the South-west [12].

\subsection{Isolation of Crude Oil Degrading Bacteria}

Crude oil degrading bacteria were isolated from the soil samples using mineral salt agar, with $1 \%(\mathrm{v} / \mathrm{v})$ crude oil as carbon source. One (1) gram of the homogenized soil samples were measured into $9 \mathrm{ml}$ of sterile distilled water in a test tube and swirled gently. $1 \mathrm{ml}$ of the sample was pipetted and serially diluted up to $10^{-3}$ dilutions. $0.1 \mathrm{ml}$ of the sample from the $10^{-2}$ and $10^{-3}$ dilutions were transferred onto the surface of a freshly prepared mineral salt agar, using the spread plate technique [3]. The plates were incubated at $30^{\circ} \mathrm{C}$ for 48 hours. After 48 hours' incubation, pure cultures were obtained by sub culturing onto fresh nutrient agar plates. The pure cultures were stored on nutrient agar slant for further use.

\subsection{Inoculum Development}

Mineral salt broth containing $0.3 \mathrm{ml}$ of crude oil was dispensed in $30 \mathrm{ml}$ quantities into four $250 \mathrm{ml}$ Erlenmeyer flasks. A loopful of the isolates were inoculated into the medium and incubated in an Orbital Shaker at $120 \mathrm{rpm}$ at $30^{\circ} \mathrm{C}$ for 24 hours. After incubation, $10 \mathrm{ml}$ of the culture broth were aseptically withdrawn and the $\mathrm{pH}$, total viable count (TVC) and optical density were measured at $550 \mathrm{~nm}$.

\subsection{Crude Oil Degrading Potentials of the Isolates}

One (1.0) milliliter of the inoculums was each added into four $250 \mathrm{ml}$ Erlenmeyer flasks containing $1 \mathrm{ml}$ of crude oil in $100 \mathrm{ml}$ of mineral salt broth. Control flask without inoculum was also prepared. The flasks were incubated in a rotary shaker at $30^{\circ} \mathrm{C}$ for 15 days, at 120 $\mathrm{rpm}$. At 5 days interval, samples were withdrawn from the flasks and the $\mathrm{pH}$, total viable count (TVC) and optical density (OD) were determined at $550 \mathrm{~nm}[13]$.

\subsection{Estimation of Crude Oil Removal by the Isolates}

The extent of removal of crude oil by the isolates was determined at the end of the incubation period. The residual oil in the flasks was extracted in a pre-weighed beaker with toluene, in a separating funnel. Extraction was repeated twice to ensure complete extraction. After extraction, toluene was evaporated in a hot air oven at $70^{\circ} \mathrm{C}$; the beaker was cooled in a desiccator and weighed. Then the percentage oil removal was calculated [14].

\subsection{Emulsification Activity}

Emulsification activity was carried out as an emulsification index $\left(E_{24}\right)$. The bacterial isolates were grown in mineral salt broth supplemented with $0.10,0.25$, $0.50,0.75$, and $1.00 \mathrm{mg} / 1$ of crude oil as sole carbon source, and incubated for 48 hours at $30^{\circ} \mathrm{C}$ at $120 \mathrm{rpm}$. One hundred (100) $\mathrm{ml}$ culture contained in $250 \mathrm{ml}$ Erlenmeyer flask was centrifuged at $1000 \mathrm{rpm}$ for 20 minutes to obtain a cell free broth supernatant. The supernatant was carefully pipetted and filtered through a filter paper to remove any suspended hydrocarbons.

Emulsification activity was carried out by mixing equal volume of crude oil and cell free broth supernatant in a test tube and vortexed at high speed for 2 minutes. The mixture was allowed to stand for 24 hours. $E_{24}$ was calculated by dividing the height of the emulsion layer by the mixture total height and multiplying by 100 [15].

\subsection{Identification of the Isolates}

The cultural and microscopic characteristics of the pure isolates were noted. Biochemical tests (such as oxidase, catalase, indole, sugar fermentation, methyl red, vogesproskauer, etc) were also carried out, with reference to the Bergey's Manual of Systematic Bacteriology.

\subsection{Statistical Analysis}

Data were analyzed and presented as mean \pm standard 
deviation (SD) of three replicates. Analysis of variance (ANOVA) was used to test significance of variations within and among the groups. When significant difference was indicated by ANOVA, the least significant difference (LSD) and Duncan multiple range test was used for pair-wise separation of the means. A statistical package for social sciences (SPSS) software was used for statistical analysis in this study and test for significance between means was implied at $\mathrm{P}=0.05$ level.

\section{Results and Discussion}

\subsection{Isolation and Identification of Crude Oil Degrading Bacteria}

Four isolates were obtained in this study. They were identified as Arthrobacter sp., Enterobacter sp., Bacillus sp., and Pseudomonas sp., based on their cultural, microscopic and biochemical characteristics. Some of the isolates (such as Bacillus sp. and Pseudomonas sp.) obtained in this study were previously reported as hydrocarbon degraders [16]. Ni'matuzahroh et al. [17] reported the isolation of Propionibacterum, sp., Bacillus sp., Corynebacterium sp. and Rothia sp. from oil sludge.

\subsection{Crude Oil Degrading Potential of the Isolates}

Figure 1 shows the variation in $\mathrm{pH}$ of the isolates during degradation of crude oil. There was an increase in $\mathrm{pH}$ of the broth cultures of the isolates from 0 to 5 days. However, from 5 to 15 days, a decrease in $\mathrm{pH}$ of the broth cultures was observed in all the isolates. An increase in optical density and total viable count of the broth cultures of the isolates was observed from 0 to 10 days of the study (Figures 2 and 3). However, a slight decrease in the optical density and total viable count of the broth cultures of the isolates was observed from 10 to 15 days of the study (Figures 2 and 3). The decrease in $\mathrm{pH}$ on the $15^{\text {th }}$ day of the study, with a concomitant decrease in optical density and total viable count, could be attributed to the mineralization of the hydrocarbons in crude oil. Sepahi et al. [18] reported that microbial degradation of hydrocarbons often leads to the production of organic acids, which probably caused the reduction in $\mathrm{pH}$. The decrease in growth on the $15^{\text {th }}$ day could be attributed to the decrease in $\mathrm{pH}$ which may have created an unfavorable environment for the isolates. The increase in growth of the isolates from 0 to 10 days of the study could be attributed to their ability to utilize crude oil as carbon source. It could also be that the cultural condition was adequate for the growth of the organisms [3]. Obire and Nwaubeta [19] reported an initial gradual increase in bacterial population following the application of petroleum hydrocarbon, but a decline as the biodegradation progressed; which supports our findings.

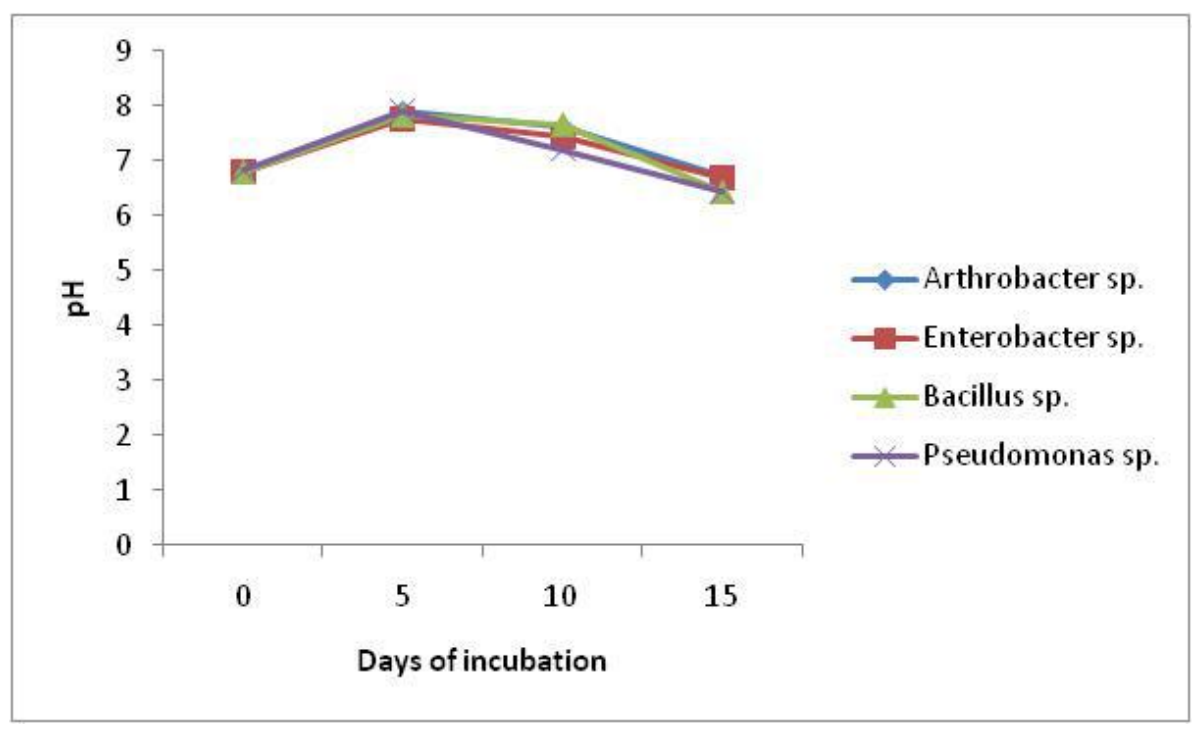

Figure 1. Variation in $\mathrm{pH}$ with time during degradation of crude oil by the isolates. 


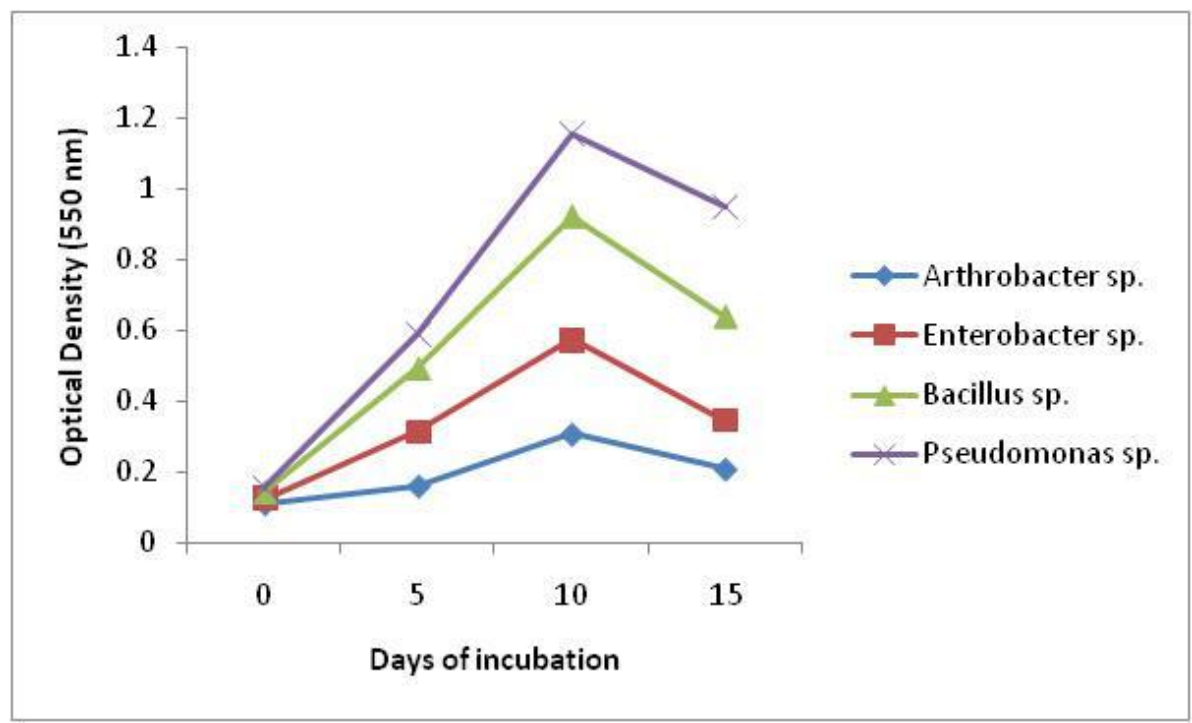

Figure 2. Variation in optical density with time during degradation of crude oil by the isolates.

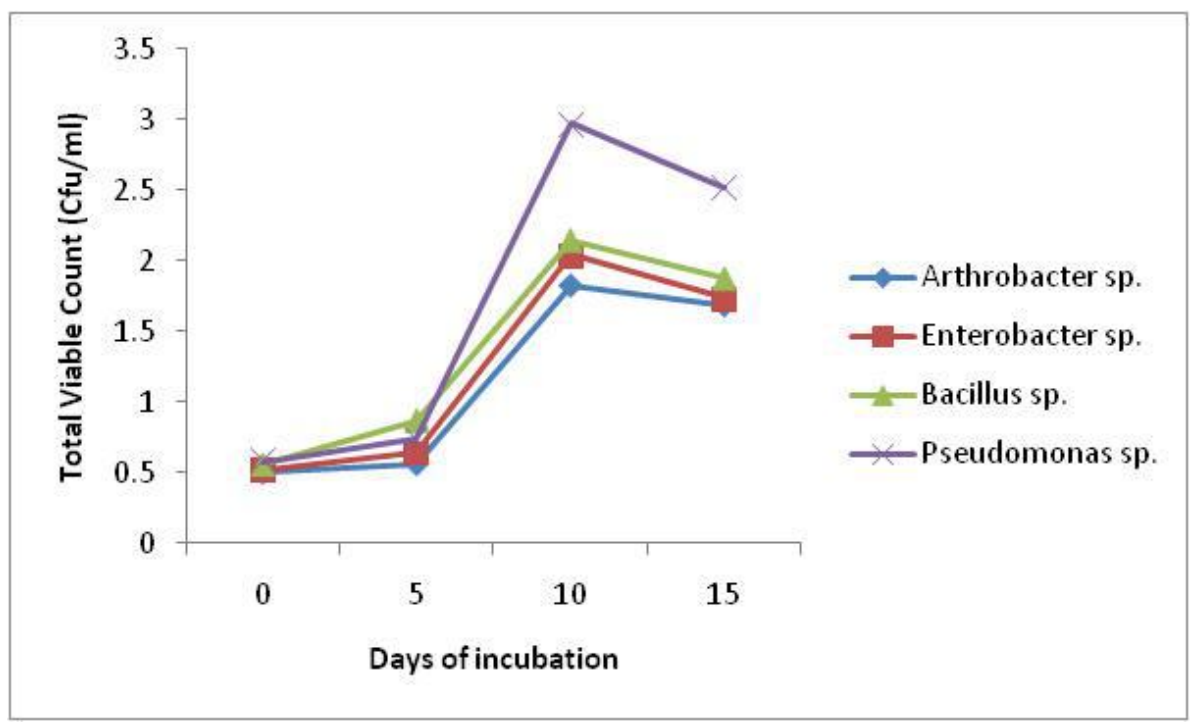

Figure 3. Variation in total viable count with time during degradation of crude oil by the isolates.

\subsection{Estimation of Crude Oil Removal by the Isolates}

Table 1 shows the extent of crude oil removal by the isolates after 15 days of the experimental period. Pseudomonas sp. showed the highest removal of $75 \%$, followed by Bacillus sp. (58.33\%), Enterobacter sp. (25\%) and Arthrobacter sp. (16.67). Highest oil removal achieved by Pseudomonas sp. in this study, could be attributed to the production of biosurfactants which emulsified the oil in the growth media, thereby enhancing its removal. However, Mbachu et al. [16] reported highest used engine oil degradation of $66.67 \%, 65.47 \%$ and $58.33 \%$ with Bacillus sp., Acinetobacter sp. and Pseudomonas sp., respectively. Different species and different life stages of organisms have been demonstrated to have different susceptibilities to pollution [20]. 
Table 1. Estimation of crude oil removal by the isolates

\begin{tabular}{|c|c|c|c|c|}
\hline Bacterial isolates & $\begin{array}{c}\text { Initial weight of crude } \\
\text { oil }(\mathrm{g})\end{array}$ & $\begin{array}{c}\text { Weight of the residual oil } \\
(\mathrm{g})\end{array}$ & $\begin{array}{c}\text { Weight of crude oil removed } \\
(\mathrm{g})\end{array}$ & $\begin{array}{c}\text { Percentage }(\%) \text { removal } \\
(\mathrm{g})\end{array}$ \\
\hline Arthrobacter $\mathrm{sp}$. & 1.2 & 1.0 & 0.2 & 16.67 \\
Enterobacter $\mathrm{sp}$ & 1.2 & 0.9 & 0.3 & 25.00 \\
Bacillus $\mathrm{sp}$ & 1.2 & 0.5 & 0.7 & 58.33 \\
Pseudomonas $\mathrm{sp}$ & 1.2 & 0.3 & 0.9 & 75.00 \\
\hline
\end{tabular}

Table 2. Emulsification index (\%) of the isolates at different crude oil concentrations.

\begin{tabular}{|c|c|c|c|c|c|}
\hline & \multicolumn{5}{|c|}{ Crude oil concentrations $(\mathrm{mg} / \mathrm{L})$} \\
\hline Isolates & 0.10 & 0.25 & 0.50 & 0.75 & 1.00 \\
\hline Arthrobacter sp. & $28 \pm 1.0^{\mathrm{a}}$ & $29.78 \pm 4.14^{\mathrm{a}}$ & $12.70 \pm 2.3^{\mathrm{a}}$ & $12.37 \pm 3.0^{\mathrm{a}}$ & $20.80 \pm 3.7^{\mathrm{b}}$ \\
Enterobacter sp. & $30.50 \pm 4.4^{\mathrm{a}}$ & $18.70 \pm 3.6^{\mathrm{b}}$ & $25.70 \pm 2.3^{\mathrm{a}}$ & $25.83 \pm 1.04^{\mathrm{a}}$ & $24.00 \pm 1.7^{\mathrm{a}}$ \\
Bacillus sp. & $20.00 \pm 1.7^{\mathrm{a}}$ & $25.30 \pm 1.5^{\mathrm{a}}$ & $50.73 \pm 5.8^{\mathrm{b}}$ & $81.80 \pm 2.8^{\mathrm{b}}$ & $40.70 \pm 2.3^{\mathrm{b}}$ \\
Pseudomonas sp. & $13.50 \pm 1.5^{\mathrm{b}}$ & $30.60 \pm 4.6^{\mathrm{b}}$ & $53.82 \pm 3.4^{\mathrm{a}}$ & $84.00 \pm 4.0^{\mathrm{b}}$ & $53.70 \pm 3.2^{\mathrm{a}}$ \\
\hline
\end{tabular}

Values are mean of three replicates, \pm standard deviation (SD). Comparison of mean along the row, values followed by letter 'a' are not different significantly, while values followed by letter ' $\mathrm{b}$ ' are significantly different at $\mathrm{P}<0.05$.

\subsection{Emulsification Activity}

The emulsification test revealed that the isolates have biosurfactant producing ability. Analysis of variance (ANOVA) showed significant differences between the emulsification indexes of the isolates at varying concentrations of crude oil. However, Duncan multiple range test and least significant difference (LSD) revealed that no obvious difference exists in the $E_{24}$ of Arthrobacter sp. and Enterobacter sp. at 0.10 to $1.00 \mathrm{mg} / 1$ crude oil concentrations $(\mathrm{P}>0.05)$. Moreover, highest $\mathrm{E}_{24}$ of $81.80 \pm 2.8$ and $84.00 \pm 4.0$ was recorded in the media containing Bacillus sp. and Pseudomonas sp., respectively at $0.75 \mathrm{mg} / \mathrm{l}$ crude oil concentration (Table 2). Highest emulsification index achieved by Pseudomonas sp. could be the reason for its highest crude oil removal observed in this study. Charan and Patel [21] reported that Pseudomonas spp. isolated from oil contaminated soil showed high potential of oil degradation and biosurfactant production, and the biosurfactant showed emulsification activity in kerosene, mannitol, glycerol and glucose. Thavasi et al. [22] reported that biosurfactant produced from a substrate can emulsify different hydrocarbons to a great extent, which confirmed its applicability against different hydrocarbon pollution. Biosurfactants have many properties including soaping, emulsification, dispersing; and have gained importance in the fields of enhanced oil recovery, environmental bioremediation, food processing and pharmaceuticals [23].

\section{Conclusions}

Among the isolates, Pseudomonas sp. has greater potential for bioremediation of crude oil polluted soil due to its high biodegradation efficiency and emulsification activity, thus could be exploited for effective clean up of crude oil polluted soil as well as biosurfactant production. Selection of Pseudomonas sp. with high biosurfactant producing ability for the scale up of bioremediation exercise is encouraged, in order to avoid the introduction to the environment of further chemicals, such as chemical surfactants, which are more toxic and non-biodegradable.

\section{Acknowledgements}

The authors are grateful to the personnel of the Microbiology Laboratory of the Department of Applied Microbiology and Brewing, Faculty of Biosciences, Nnamdi Azikiwe University, Awka.

\section{REFERENCES}

[1] Oil price.com. What is Crude Oil? A detailed explanation on this essential fossil fuel. Retrieved from http:/www. oilprice.com. The No. 1 source for oil and energy news, 2009.

[2] Dhar, K., Dutta, S. and Anwar, S. Biodegradation of petroleum hydrocarbon by indigenous fungi isolated from Ship breaking yards of Bangladesh. International Research Journal of Biological Sciences, 3(9), 22-30, 2014.

[3] Mbachu, A.E., Chukwura, E.I. and Mbachu, N.A. Evaluation of the effectiveness of fungi (Candida tropicalis and Aspergillusclavatus) in bioremediation of used engine oil contaminated soil using bioaugmentation technique. International Journal of Environment, Agriculture and Biotechnology, $3(4)$ : 11751182 , 2018.http://dx.doi.org/10.22161/ijeab/3.4.4.

[4] Okpowasili, G. C. and Odokuma, L.O. Effect of salinity on biodegradation of oil spills dispersants. WasteManagement, 10(2): $141-146$,

1990.https://doi.org/10.1016/0956-053X(90)90118-5

[5] Abosede, E.E. Effect of crude oil pollution on some soil physical properties. IOSR Journal of Agriculture and Veterinary $\quad$ Science, $\quad 6(3), \quad 14-17$, 2013.www.iosrjournals.org

[6] Prakash, B. and Irfan, M. Pseudomonas aeruginosa is present in crude oil contaminated sites of Barmer Region, India. Journal of Bioremediation \&Biodegradation, 2(5): 
129, 2011. doi:10.4172/2155- 6199.1000129.2.

[7] Hidayat, A. and Tachibana, S. Biodegradation of aliphatic hydrocarbon in three types of crude oil by Fusarium sp. F092 under stress with artificial sea water. Journal of Environmental Science and Technology, 5(1): $64-73$, 2012. Doi:10.3923/jest.2012.64.73.

[8] Falode, O.A., Adeleke, M.A. and Ogunshe, A.O. Evaluation of indigenous biosurfactant producing bacteria for de-emulsification of crude oil emulsions. Microbiology Research Journal International, 18(3): 1-9, 2017.

[9] Thavasi, R., Sharma, S. and Jayalakshmi, S. Evaluation of screening methods for the isolation of biosurfactant producing marine bacteria. Journal of Petroleum \& Environmental Biotechnology, S1: 001, 2011, doi: 10.4172/2157-7463.S1-001.

[10] Walter, V., Syldatk, C. and Hausmann, R. Screening concepts for the isolation of biosurfactant producing microorganisms. Madame Curie Bioscience Database. Austin (TX): Landes Bioscience; 2000-2013. Available: http://www.ncbi.nlm.nih.gov/boks/NBK6189/,http://www. ncbi.nlm.nih.gov/books/NBK5974/ (Accessed August 13, 2016).

[11] Khire, J.M. Bacterial biosurfactants and their role in microbial enhanced oil recovery (MEOR) In: Biosurfactants, Vol. 672 of the series Advances in Experimental Medicine and Biology, Chapter, Section II, Ed. RamkrishnaSenMTech, PhD. Springer New York, 146-157, 2010.

[12] Egele, V. Historical and background of Ohaji-Egbema Local Government Area. egelevictor.wordpress.com, 2015.

[13] Okpokwasili,G.C. and Nwosu, A.I. Degradation of aldrine by bacterial isolates. Nigerian Journal of Technological Research, 2(1): 1-6, 1990.

[14] Oloke, J.K. and Glick, B.R. Production of bioemulsifer by an unusual isolate of salmon/ red melanin containing Rhodotorulaglutinis. African Journal of Biotechnology, 4(2): 164-171, 2005

[15] Techaoel, S., Lumyong, S., Prathumpai, W., Santiarwarn, D. and Leelapornpisid, P. Screening, characterization and stability of biosurfactant produced by Pseudomonas aeruginosa SCMU106 isolated from soil in Northern Thailand. Asian Journal of Biological Sciences, 4, 340 351, 2011. http://scialert.net/doi: 10.3923/ajbs.2011.340.351.

[16] Mbachu, A.E., Onochie, C.C., Agu, K.C., Okafor, O.I. and Awah, N.S. Hydrocarbon degrading potentials of indigenous bacteria isolated from Auto-Mechanic Workshops at Mgbuka-Nkpor, Nigeria. Journal of Global Biosciences, 3(1): 321-326, 2014. http://mutagens.co.in

[17] Ni'matuzahroh, Sari SK, Ningrum IP, Pusfita AD, Marjayandari L, Trikurniadewi N, Ibrahim SNMM, Fatimah, Nurhariyati T, Surtiningsih T, Yuliani H. The potential of indigenous bacteria from oil sludge for biosurfactant production using hydrolysate of agricultural waste. Biodiversitas 20: 1374-1379, 2019.

[18] Sepahi, A.A., Dejban, G.I., Emami, M. and Nakhoda, A.M. Isolation and characterization of crude oil degrading Bacillus spp. Iranian Journal of Environmental Health,
Science and Engineering, 5, 149-154, 2008.

[19] Obire, O. and Nwaubeta, O. Effects of refined petroleum hydrocarbon on soil physicochemical and bacteriological characteristics. Journal of Applied Sciences and Environmental Management, 6(1), 39-44, 2002.

[20] Vanishree, M., Thatheyus, A.J. and Ramya, D. Biodegradation of petrol using the Fungus Penicillium sp. Science International, 2 (1): 26-31, 2014.

[21] Charan, N. and Patel, S., Isolation of Biosurfactant Producing Organisms from the Petroleum Contaminated Soil in Gujarat, International Journal of Pure and Applied Bioscience $\quad 5(5)$ : $\quad 893-910, \quad 2017$. doi:http://dx.doi.org/10.18782/2320-7051.5411.

[22] Thavasi, R., Jayalakshmi, S. and Banat, I.M. Biosurfactants from marine bacterial isolates. In A. Mendez-Vilas (Eds.), Current Research, Technology and Education Topics in Applied Microbiology and Microbial Biotechnology, 1367-1373, 2010.

[23] Priya, T. and Usharani, G. Comparative study for biosurfactant production by using Bacillus substilis and Pseudomonas aeruginosa. Batany Research International, 2(4), 284-287, 2009. 